on "The True Mahoganies," by Mr. R. A. Rolfe, and "The Jerusalem Artichoke," by Mr. C. C. Lacaita; the latter is an exhaustive discussion on the introduction of this vegetable to the Old World and the origin of its popular name. An account is given of Lord Ventry's experiments on growing New Zealand flax in Ireland; the evidence goes far to show that the possibility of growing it in South-West Ireland as a commercial undertaking is an established fact. "Silver-leaf Disease" and "The Skin-spot Disease of Potatotubers" are the titles of two important contributions on plant-diseases by Messrs J. Bintner and M. Nest Owen respectively. Results of botanical exploration are embodied in Dr. Hemsley's account of the flora of Aldabra and adjacent islands and in Mr. Turrill's résumé of the botanical results of Swedish South American and Antarctic expeditions.

The more purely botanical papers include a careful examination, by Sir David Prain and $\mathrm{Mr}$. Burkill, of the identity of the plant, or plants, known under the name Dioscorea sativa; and a revision by $\mathrm{Mr}$. WV. B. Grove of the species of the fungus genus Phoma. There is also an historical account of the botanic garden of Pamplemousses, Mauritius; and the new flagstaff at Kew and its erection are described in detail. The obituary notices include those of Prof. J. W. H. Trail of Aberdeen and Prof. W. G. Farlow of Harvard.

The Story of Milk. By J. D. Frederiksen. Pp. $\mathrm{xx}+\mathrm{I} 88$. (New York: The Macmillan

Co. ; London : Macmillan and Co., Ltd., I9r9.)

Price $9 s$. net.

THE author tells his story in a clear and interesting manner, and the general reader, as well as the student of domestic science or dairying, will follow the contents of the book with pleasure and profit. The subject-matter is sound, and the concise, practical directions will be valuable to anybody who is acquainted with the general methods of butter-making and cheese-making.

There are sections dealing with the composition and properties of milk, the testing of milk, the part played by enzymes and bacteria, and the methods by which organisms are utilised or controlled. Milk supply and butter-making and the manufacture of ice cream are the chief subjects of another section. As the book is written for American readers, the sixteen pages devoted to recipes for ice cream are perhaps not excessive, and they will not fail to raise in the English mind a feeling of envy that such delectable things as parfaits and mousses are not more general.

Cheese-making is well dealt with, and working details are supplied, whilst the methods adopted in the manufacture of condensed milk, milk powder, and cascin are briefly sketched.

Very rightly the food value of milk is given a prominent place, and the recipes for dishes in which milk or cheese forms an important part are attractive, and should be found very useful to NO. 2634 , VOL. IO5? many. A certain amount of historical information is given, and the names and labours of notable workers in the various branches of dairying are also to be found in the book.

\section{A First Year Physics for Junior Technical Schools.}

By G. W. Farmer. With an Introduction by S. C. Laws. Pp. $x+183$. (London: Longmans, Green, and Co., 1920.) Price $4^{s} .6 d$.

THis book is intended for use by boys of between twelve and fourteen years of age who have just completed the elementary-school course and are passing to a more advanced curriculum such as is provided in the junior technical, central, or continuation school. It may suit the courses in some of these institutions, but if this is to be the only kind of instruction in physics during the first year of study, the diet cannot be said to be too stimulating. The work is concerned almost entirely with the use of simple measuring instruments. The description of three methods of verifying "Pythagoras," of four ways of measuring the weight of a cubic centimetre of water, and of no fewer than eleven experiments to show that air exerts pressure indicates too much devotion to completeness of detail at the expense of time which could be spent more profitably in giving the pupils glimpses at the marvels of Nature by which they are surrounded.

The Struggle in the Air, I914-18. By Major Charles C. Turner. Pp. viii +288 . (London :

Edward Arnold, 1919.) Price I 5 s. net.

MAJOR TURner gives an extremely instructive and readable account of the development of aircraft from 1914 to 1918. With the work of a generation compressed into four years of war, it is not surprising that the developments and events narrated crowd upon each other in bewildering succession. The psychology of flying and the official requirements as regards details of machines for war purposes form exceptionally valuable chapters of the book.

Calculation of Electric Conductors. By William T.

Taylor. Pp. 34. (London: Constable and Co., Ltd., I919.) Price ros. 6d. net.

A chart supplied with the book enables the electrical engineer to determine the size of a conductor required to convey a current of a given value when the voltage drop and length of cable are given, or to find any of these quantities when the three others are given. With the help of the explanatory text all the ordinary cables and systems can be thus dealt with.

Revision Arithmetic, Logarithms, Slide Rule, Mensuration, Specific Gravity, and Density. By Terry Thomas. Second edition, revised. Pp. 62. (London: Crosby Lockwood and Son, 1920.) Price 2s. $6 d$.

Nimerical, examples and answers are given. The standard is that of the Army and Navy Entrance Examinations. 